\title{
Distribution patterns of macrozooplankton assemblages in the southwest Atlantic
}

\author{
G. A. Tarling ${ }^{1}$, P. Ward ${ }^{2}$, M. Sheader ${ }^{1}$, J. A. Williams ${ }^{1}$, C. Symon ${ }^{3}$ \\ ${ }^{1}$ Oceanography Department, Southampton University, Southampton SO9 5NH, United Kingdom \\ ${ }^{2}$ British Antarctic Survey (N.E.R.C.), Madingley Rd, Cambridge CB3 OET, United Kingdom \\ ${ }^{3}$ Oslo \& Paris Commissions, New Court, 48 Carey Street, London WC2A 2JE, United Kingdom
}

\begin{abstract}
A zooplankton net sampling survey was conducted in the southwest Atlantic between $34^{\circ}$ and $55^{\circ} \mathrm{S}$ during austral spring 1990 . The survey grid covered shelf, slope and oceanic regions and contained 44 stations spaced at $100 / 200 \mathrm{~km}$ intervals. Sampling was carried out with an RMT8 net which was deployed obliquely from the surface to either $200 \mathrm{~m}$ over shelf regions or $300 \mathrm{~m}$ oft-shelf. A total of 155 species were identified from 9 taxonomic groups including euphausiids, hyperind amphipods, chaetognaths, salps, siphonophores and nektonic/planktonic fish. Log-transformed relative numerical abundances for each species were used in hierarchical classification to elucidate macroscale patterns of distribution. Factor analysis was also used on the most abundant and widely distributed species to reveal mesoscale patterns. Classification analysis produced 4 station groups which showed distinct geographic integrity and strong relationships to the positions of water masses. Group 1 was related to the Falkland shelt, Group 2, the Polar Frontal Zone (PFZ), Group 3, the Sub-Antarctic water mass (SAZ) and Group 4, the Sub-Tropical water mass (STZ). The dissimilarity matrix showed that the STZ group was very distant from the other 3 station groups, suggesting that its fauna is distinctly different to that found throughout the rest of the survey grid. By far the highest number of species showed strongest fidelity to the STZ group with 5 out of the 8 species clusters associated to that station group. Factor analysis gave further resolution to the station group patterns. The distribution of Factor 1 suggested that the warm Falkland Current return carried sub-tropical species into the SAZ. Factors 2 and 3 showed that there were at least 2 distinct faunal zones within the PFZ and Factor 4 highlighted the potential influence of the Falkland Current on the distribution of the shelf community. Overall it was evident that there was a strong correspondence between the distribution of faunal groups and water masses. However, the differences between SAZ, PFZ and Falkland shelf groups were mostly characterised by differences in abundance, whereas the STZ/SAZ boundary was marked by distinct differences in species composition.
\end{abstract}

KEY WORDS: Zooplankton Assemblages - Mesoscale - Water masses Southwest Atlantic Ocean

\section{INTRODUCTION}

There has been little study of zooplankton ecology in the southwest Atlantic Ocean compared to other oceanographic regions (Angel 1979, Boltovskoy 1986). The emergence of squid fisheries in the region has increased interest in the ecology of the area, especially the dispersal and recruitment of squid stocks (Rodhouse \& Hatfield 1990, Hatfield 1992, Rodhouse et al. 1992). Zooplankton communities support higher trophic levels and are an important determinant on the potential size of a fishery (Barber et al. 1985). Investi- gating zooplankton community structure and distribution patterns is therefore an essential step towards understanding the trophic ecology of a region and successfully managing its fisheries (Fearon 1986, Pillar et al. 1992).

Hydrographically, the region is complex, containing 2 strong western boundary currents in a dynamic region of mixing (Fig. 1). Between the 2 currents, a multitude of thermal phenomena exist in various stages of development and decay, including warm and cold core eddies and warm filament structures. There is considerable variation in the position of fronts and a 
strong contrast in the physical attributes of water masses. Temperature and salinity drop markedly from the Sub-Tropical to the Polar Frontal waters (Deacon 1933, Peterson \& Whitworth 1989) and the upwelling of Antarctic surface water results in high oxygen saturation and nutrient levels in the sub-polar waters (Petersen \& Whitworth 1989). The region is also characterised by an extensive shelf area.

There have been a number of expeditions that have surveyed this area, e.g. 'Discovery' (Kemp \& Bennet 1929), 'Dana' (Jespersen 1923, 1935), 'Meteor' (Hentschel 1938). More recently, the adjacent Patagonian shelf has been extensively surveyed by the 'Shankai Maru' and the 'Walter Herwig' (Dadon 1989, Mazzoni 1990). Nevertheless, most of the zooplankton analyses were restricted to single taxonomic groups. An exception was the study of Dadon \& Boltovskoy (1982), in which distributional records of a number of taxonomic groups were analysed with multivariate techniques. Their proposed distribution patterns were derived from a large amount of biological information compiled from the literature. However, the sampling methods of the cited zooplankton surveys varied and their quantitative information was not comparable. The study was therefore restricted to a qualitative approach, analysing information based on the presence or $a b$ sence of species in designated regions.

This study aimed to produce a greater insight into the distribution of zooplankton communities in the region through a quantitative consideration of a larger range of taxonomic groups obtained from a single, synoptic survey. The influence of hydrographic factors on the distribution of faunal groups was assessed by relating distribution patterns to the position of water masses and sea surface temperatures. Although the nets were towed obliquely and were selective towards the macrozooplankton, the community distribution patterns obtained have one of the broadest taxonomic scopes and finest degrees of geographic resolution yet obtained in this area.

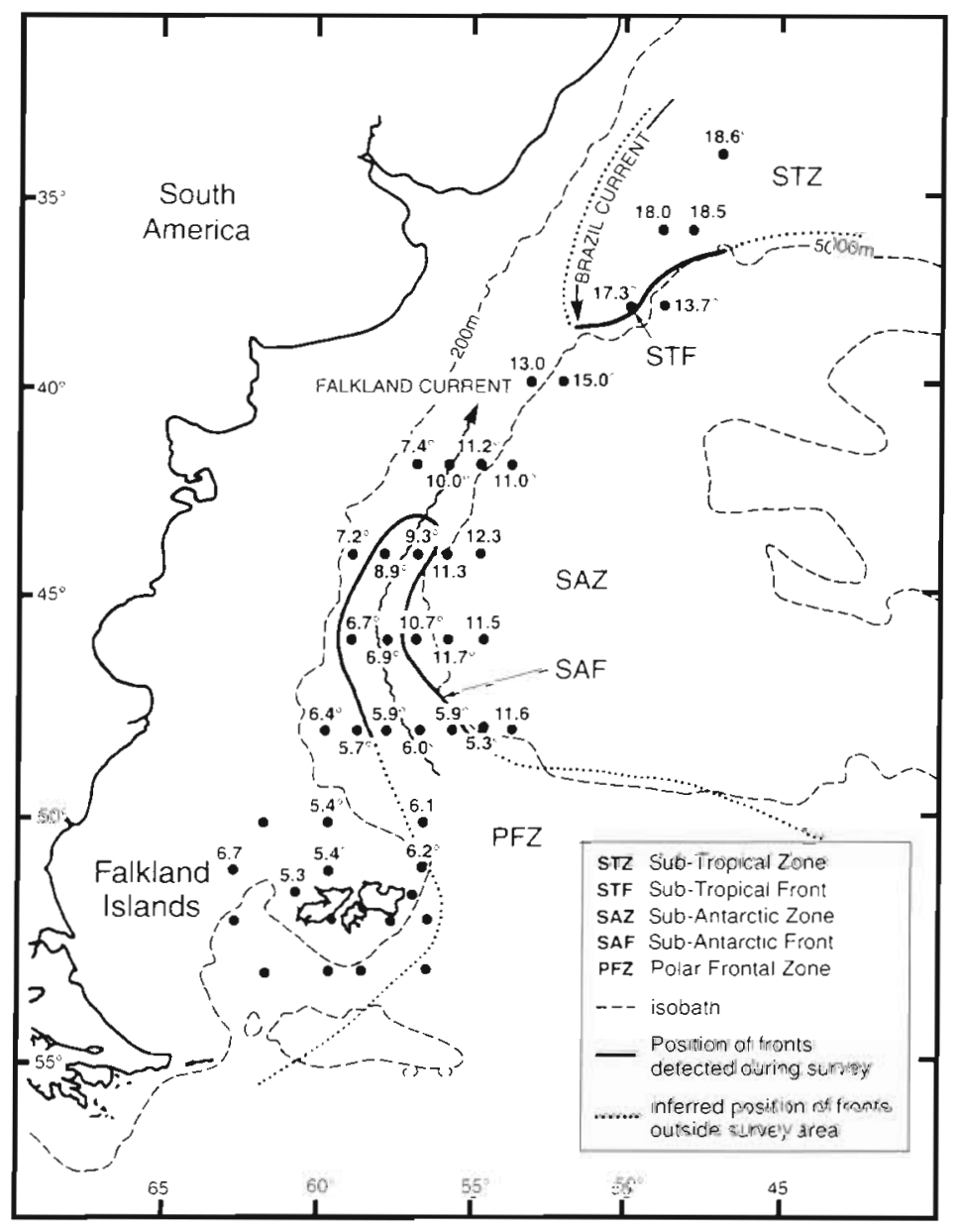

Fig. 1. Position of major oceanographic features in relation to the samplang stations and spot surface temperatures

\section{METHODS}

Hydrography. The hydrography of the southwest Atlantic Ocean has been reviewed by Rodhouse et al. (1992) and only a summary of the main oceanographic features is given here.

The region is hydrographically complex, containing 2 significant western boundary currents and their highly energetic confluence. The Falkland Current is approximately $100 \mathrm{~km}$ wide and originates as a branch of the Antarctic Circumpolar Current, carrying Sub-Antarctic and Polar Frontal Zone water northwards along the shelf break. The western edge of the Falkland Current is approximately coincident with the $200 \mathrm{~m}$ isobath while the northern edge is bounded by the warmer waters of the Brazil Current. The Brazil Current (the western boundary current of the South Atlantic Sub-Tropical Gyre) carries Sub-Tropical waters from $8^{\circ} \mathrm{S}$ southwards until meeting the Falkland Current at a confluence referred to as the Sub-Tropical Front (STF). The STF is particularly unstable and there is considerable variability in its location because of the frequent formation of mesoscale eddies. The 2 currents subsequently move offshore and, with the Brazil Current dominating, move in a southeasterly direction to at least $40^{\circ} \mathrm{S}$. The currents then separate, the Brazil Current turning north- 
wards, whilst the Falkland Current returns in a southeasterly direction, close to the $5000 \mathrm{~m}$ isobath.

Following the nomenclature of Peterson \& Whitworth (1989), the STF separates the Sub-Tropical Zone (STZ) to the north and the Sub-Antarctic Zone (SAZ) to the south. Further south, the SAZ is limited by the Sub-Antarctic Front (SAF) below which lies the Polar Frontal Zone (PFZ). The PFZ is strongly associated with the Falkland Current and is a complex region containing meandered isolated eddies of Sub-Antarctic Water in addition to Antarctic Intermediate Water (AAIW) which has risen in the water column.

The positions of the STF and SAF were located with the XBT (expendable bathythermograph) temperaturedepth profiles, with reference to the criteria outlined by Peterson \& Whitworth (1989). The relationship between the location of sampling stations, spot surface temperatures and the distribution of fronts is presented in Fig. 1.

Sampling methods. A full description of the study area and sampling methods is given in Rodhouse et al. (1992) and only a brief summary is given here. This report analyses the RMT8 catches of the MV 'Falkland Protector' survey carried out between 7 October and 9 November 1990. It consisted of a series of latitudinal transects split into northern and southern phases. The northern phase covered the slope waters adjacent to the Patagonian shelf and the western sector of the Argentine basin between $34^{\circ}$ and $48^{\circ} \mathrm{S}$. The southern phase was carried out in the vicinity of the Falkland Islands $\left(50^{\circ}\right.$ to $\left.53^{\circ} \mathrm{S}\right)$ and covered shelf waters of $200 \mathrm{~m}$ or less. An RMT8 net, with a $4.5 \mathrm{~mm}$ mesh, was deployed in a downwards oblique fashion on both phases although the deployment parameters differed in each phase. In the northern phase 90 min tows, from 0 to $300 \mathrm{~m}$, were carried out, whereas in the southern phase, tows were for $60 \mathrm{~min}$ from 0 to $200 \mathrm{~m}$. Towing speed was 2 knots. All stations were sampled at the time of arrival. Out of the 44 stations, 18 were sampled during night-time, 3 during either dusk or dawn and the remainder during daytime.

Flow meters were not used but filtered volume was estimated using equations derived by Pommeranz et al. (1982) for obliquely towed RMT8 nets. The study found RMT8 nets to always be stable and concluded that the equations allowed reliable estimates of volume filtered. With a net width $(W)$ of $2.83 \mathrm{~m}$, height $\left(H_{0}\right)$ of $4.0 \mathrm{~m}$ (Clarke 1969), and velocity $(V)$ of 2 knots, the effective mouth area was $9.8302 \mathrm{~m}^{2}$. The distance travelled during the 90 min northern phase tows was $5556 \mathrm{~m}$ which gave a filtered volume of $54687 \mathrm{~m}^{3}$. The 60 min southern phase tows can be assumed to filter $2 / 3$ of this amount, which was $36468 \mathrm{~m}^{3}$.

Vertical temperature profiles were obtained to a maximum of $750 \mathrm{~m}$ using $T 7$ XBTs at each of the northern phase stations. Additional XBT deployments were also made to the east of the survey area during the transit stage. In the southern phase, profiles were obtained on 2 transects. Sea surface temperatures were taken at each station at the start of each tow.

Net samples were immediately fixed in $4 \%$ formalin and later transferred to Steedman's solution (Steedman 1976) during sorting in the laboratory.

Sub-sampling methods. A preliminary sort of the sample was carried out during which most of the larger organisms such as fish, decapods and large salps were removed and counted. The sample was then repeatedly halved using a Folsom splitter and taxonomic groups removed when sub-samples contained approximately 150 individuals. Where possible, individuals were identified to the species level with the aid of a microscope.

In order to estimate sub-sampling errors, coefficients of variation (CV) were calculated for 6 major taxa (chaetognaths, euphausiids, siphonophores, amphipods, salps and decapods) (Van Guelpen et al. 1982). A representative sample containing a typical mixture of animals was divided into $1 / 8$ aliquots. The numbers of the 6 taxa in each of the aliquots were then counted and the CV calculated for each taxa. CVs were between 5.6 and $10.1 \%$, giving an average of $8 \%$ for each taxon where between 100 and 150 individuals were counted, a degree of error which should not blur the major distribution patterns present.

\section{RESULTS}

A total of 155 zooplankton species were identified in the 9 taxonomic groups considered in this study. The majority of taxa were not widespread and only $10 \%$ of the species occurred at more than $70 \%$ of the stations (Fig. 2). The significant positive correlation between logged frequency of occurrence $(f)$ and logged total abundance $(N)$ showed that, in the survey as a whole, widespread species had the highest abundances. Plotting log average abundance $(N / f)$ against rank determined from the frequency of occurrence (Fig. 3) illustrated that widespread species made up the majority of individuals caught at each station.

Typical widespread species included the hyperiid amphipod Themisto gaudichaudi, the chaetognath Sagitta gazellae, the siphonophore Chelophyes appendiculata and the euphausiids Euphausia vallentini, E. lucens and Thysanoessa gregaria

Two multivariate techniques were used in the analysis. The first, hierarchical classification, imposes a framework onto a data set through grouping similar entities together into clusters. It is an effective technique when community variation is discontinuous and is useful in this context in highlighting biogeagraphic zones. Although the majority of species were sparsely 


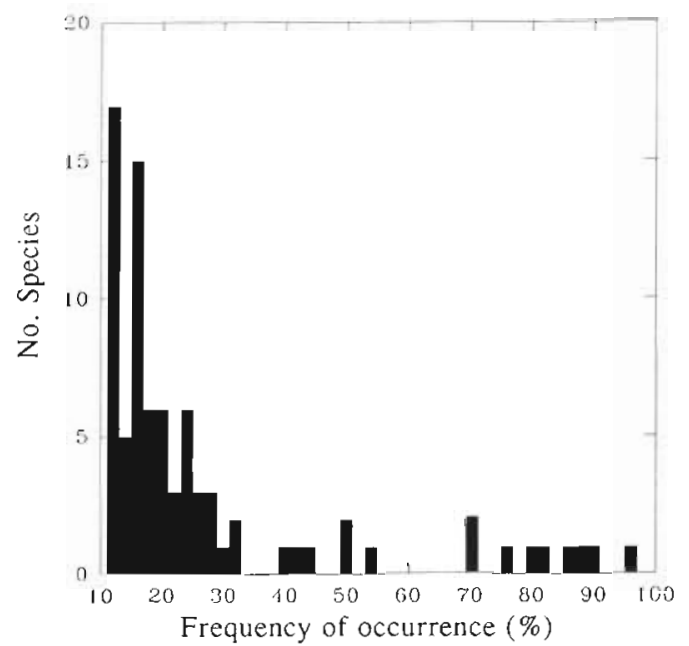

Fig. 2. Occurrence frequencies of species

distributed, a small number of highly abundant species were found continuously throughout the study area. Factor analysis was considered a more appropriate technique to apply to this subset of species since it condenses data matrices into low dimensional space. This preserves the continuous nature of the data set and allows areas of strongest association to be highlighted within the study area.

Possible day/night differences in the catch were investigated using a combination of the Mann-Whitney Rank Sum test and $t$-tests. A total of 14 species were found to show a significantly greater abundance in night-time compared to daytime catches, those of note being Thysanoessa gregaria, Nematoscelis megalops, most of the decapods and many myctophiid fish. These species were subsequently excluded from further analysis.

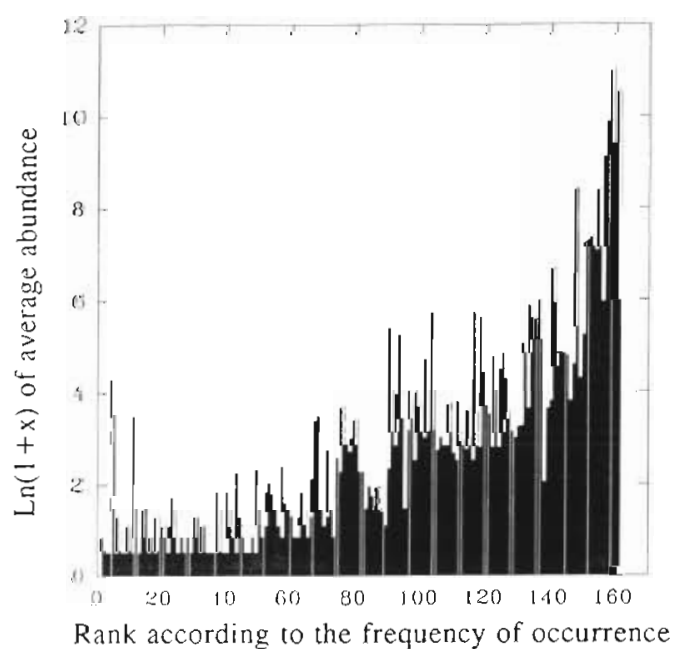

Fig. 3. The logged average abundance of species against rank determined from the frequency of occurrence

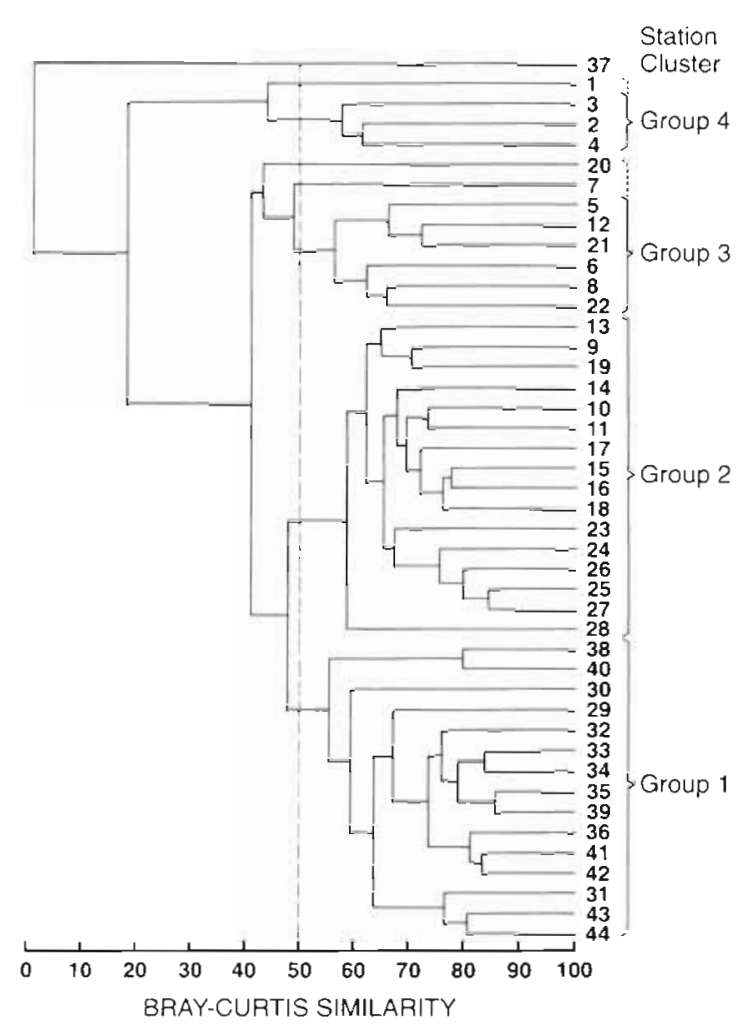

Fig. 4. Dendrogram showing station clusters

\section{Hierarchical classification}

Station clusters. The data set was transformed using $\ln (1+x)$ and clustered using the Bray-Curtis similarity coefficient and average linkage (Fig. 4). Experimental separations of groups at a number of similarity levels were carried out with the aim of revealing associations between stations as fully as possible. Separation at the $50 \%$ level of similarity was eventually decided upon since it was a suitable compromise between the strength of group association and the number of clusters. The geographic distribution of these groups is illustrated in Fig. 5, with the dissimilarity matrix shown in Table 1.

Species clusters. A second classification, this time involving the clustering of species, was carried out in or-

Table 1. Average coefficients of dissimilarity between all members of each station group, using the Bray-Curtis similarity coefficient

\begin{tabular}{|ccccc|}
\hline & Group 1 & Group 2 & Group 3 & Group 4 \\
\hline Group 1 & 0 & & & \\
Group 2 & 52.23 & 0 & & \\
Group 3 & 64.90 & 54.04 & 0 & \\
Group 4 & 93.35 & 90.17 & 79.07 & 0 \\
\hline
\end{tabular}




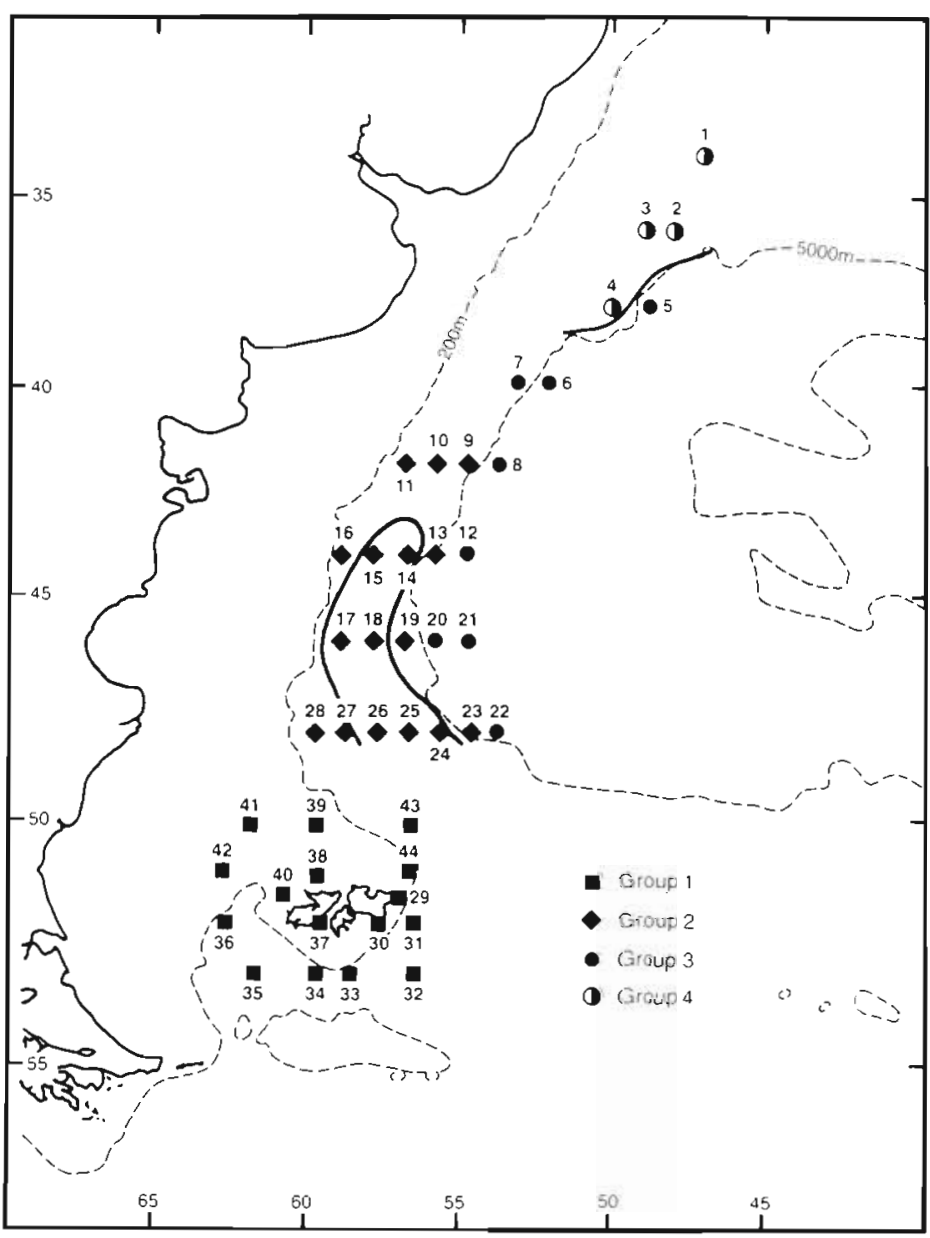

Fig. 5. Distribution of stations grouped by hierarchical classification was accepted only if all of its species showed significant differences between 3 of the 4 station groups. Of the 9 species clusters, 8 passed this criterion. Finally the strength of association between the station groups and each of the species within the 8 species clusters was calculated using the Bray-Curtis similarity coefficient. Table 2 shows the species in each of the 8 species clusters and the station groups to which they show strongest association. Table 3 further shows the number of species found, the number of species showing strongest fidelity, the Shannon-Wiener Diversity Index (H) (Shannon \& Weaver 1963) and the Equitability Index $(J)$ (Lloyd et al. 1964) of species in each of the station groups.

Factor analysis. Factor analysis is best suited to continuous data and for it to be a robust analytical technique, it is necessary to restrict the data set to a subset of species that are sufficiently widespread and abundant. A number of data sets, containing different numbers of species, were experimented with and their robustness was tested for by using a variety of transformations and checking for consistency in the results. The most robust results were obtained with a data set containing species that occurred in at least $20 \%$ of the stations.

Principal Component Factoring was chosen in preference to other factor analysis techniques since it does not make assumptions about the communality and is more appropriate in the earliest stages of an investigation (Davies 1982), Once the initial principal com- der to determine the relationship between species and station clusters. A data set, restricted to species occurring at more than 3 stations, was again transformed $[\ln (1+x)]$ and clustered as above (Fig. 6). The overall aim was to obtain strongly associated species clusters with contrasting levels of station abundance in different station group regions. As for the station groups, separation of clusters at the $50 \%$ level of similarity was considered to be a suitable compromise between the number of clusters and the strength of group association. This gave 9 groups containing 2 or more species. Each species in each species cluster was then tested for significant differences in abundance between station groups. Rare species, with non-normal distributions, were tested using a Kruskall-Wallis test, whilst a Dunn's test was applied to common, normally distributed species. A species cluster

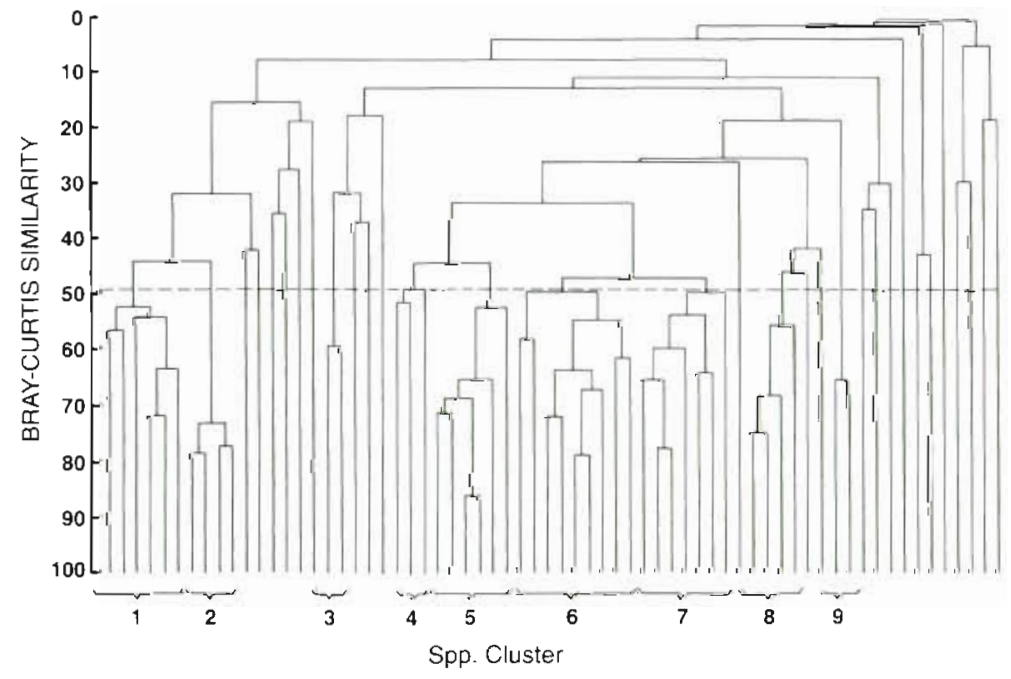

Fig. 6. Dendrogram showing species clusters 
Table 2. Species found within each species cluster and the station cluster to which they show the strongest association

\begin{tabular}{|c|c|}
\hline Species cluster & Station cluster \\
\hline $\begin{array}{l}\text { Spp. cluster } 1 \\
\text { Protomyctophum bolini } \\
\text { Primno macropa } \\
\text { Salpa thompsoni (aggregate) } \\
\text { Salpa thompsoni (solitary) } \\
\text { Stylocheiron maximum } \\
\text { Euphausia similis } \\
\text { E. triacantha }\end{array}$ & 2 \\
\hline $\begin{array}{l}\text { Spp. cluster } 2 \\
\text { Sagitta gazellae } \\
\text { Euphausia lucens } \\
\text { E. vallentini } \\
\text { Themisto gaudichaudii }\end{array}$ & 1 \\
\hline $\begin{array}{l}\text { Spp. cluster } 3 \\
\text { Diaphus hudsoni } \\
\text { Argyropelecus hemigymnus } \\
\text { Lampanyctus pulsillus }\end{array}$ & 3 \\
\hline $\begin{array}{l}\text { Spp. cluster } 4 \\
\text { Vinciguerria powerie } \\
\text { Scopelosaurus spp. } \\
\text { Iasis zonaria } \\
\text { Lampanyctus pulsillus } \\
\text { Sio nordenskjoldii } \\
\text { Scina spp. }\end{array}$ & 4 \\
\hline $\begin{array}{l}\text { Spp. cluster } 5 \\
\text { Hemityphis tenuimanus } \\
\text { Brachyscelus crusculum } \\
\text { Phrosina semilunata } \\
\text { Platyscelus armatus } \\
\text { Streetsia challengeri } \\
\text { Phronima bucephalata } \\
\text { Thysanopoda monocantha } \\
\text { Argyropelecus aculeatus } \\
\text { Valencienellus tripunctulatus }\end{array}$ & 4 \\
\hline $\begin{array}{l}\text { Spp. cluster } 6 \\
\text { Nematobranchion flexipes } \\
\text { Euphausia spinifera } \\
\text { E. recurva } \\
\text { Stylocheiron abbreviatum } \\
\text { Phronima semilunata }\end{array}$ & 4 \\
\hline $\begin{array}{l}\text { Spp. cluster } 7 \\
\text { Sagitta planctonis } \\
\text { S. hexaptera } \\
\text { Hippopodus hippopus } \\
\text { Chelophyes appendiculata }\end{array}$ & $3 / 4$ \\
\hline $\begin{array}{l}\text { Spp. cluster } 8 \\
\text { Anguilliformes larvae } \\
\text { Paraphronima gracilis }\end{array}$ & 4 \\
\hline
\end{tabular}

ponent analysis was carried out on the $\ln (1+x)$ transformed data set, Cattell's Scree test was used to determine the number of factors, following the recommendation of Angel \& Fasham (1975). The test found 6 factors to have eigenvalues greater than unity and which accounted together for $73.2 \%$ of the variance. The factor matrix was subsequently rotated using the
Varimax rotation method in order to improve the interpretation of factors. Since the eigenvalues may be affected by rotation, it was necessary to compare the factor matrices before and after rotation to check that the factors had not changed in order of importance. The lists of species associated with each factor were comparable and it was evident that the order of importance had remained the same after rotation. Table 4 lists the analysed species beneath the factor to which they had the highest loading.

The geographical integrity of these factor groups was determined from their factor scores, $F$, using a method illustrated by Angel \& Fasham (1975) involving the application of the following equation from Harman (1967):

$$
F_{q i}=\sum_{j=1}^{n} a_{j q} z_{j i} / \lambda_{q}
$$

where $n$ is the number of taxa, $a_{j q}$ is the factor loading of the $j$ th species on the $q$ th factor, $\lambda_{q}$ is the eigenvalue for the $q$ th factor and $z_{j}$ is the double-root transformation of the abundance of taxon $j$ in haul $i$.

A high factor score means that the factor group is strongly associated with that station. Factor scores for the first 4 factors are shown in Fig. 7 .

\section{DISCUSSION}

\section{Relationship to environmental features}

When interpreting these results, one of the first considerations must be the scale of resolution achieved by each multivariate analysis. Hierarchical classification divided stations into cluster groups according to degrees of association and imaging these patterns provided a resolution of around $1000 \mathrm{~km}$. Under the definitions of scale given by Haury et al. (1978), such patterns would be termed macroscale and would show a moderate contrast in species composition as well as highs and lows in species abundance. This scale would be appropriate for considering the affinity of faunal groups to water masses. Imaging the patterns from factor analysis gave a finer resolution (between 500 and $1000 \mathrm{~km}$ ) because, in addition to simply categorising associated stations, the strength of a factor group's relationship to a station was resolved. The potential resolution of this analysis was approximately mesoscale (Haury et al. 1978), and would be able to define populations of faunal groups associated to features such as eddies and boundary currents.

It can be seen that the cluster groups produced by hierarchical classification in Fig. 5 are geographically distinct and define 4 zones within the study area. Station. group 1 comprises the shelf stations around the Falkland Islands, group 2, stations from the edge of the Patagon- 
Table 3. Attributes of the groups obtained from hierarchical clustering

\begin{tabular}{|ccccc|}
\hline & $\begin{array}{c}\text { Total spp. } \\
\text { present }\end{array}$ & $\begin{array}{c}\text { No. of spp. } \\
\text { with strongest } \\
\text { fidelity }\end{array}$ & $\begin{array}{c}\text { Shannon- } \\
\text { Wiener } \\
\text { Index }(H)\end{array}$ & $\begin{array}{c}\text { Equitability } \\
\text { Index }(J)\end{array}$ \\
\hline Group 1 & 19 & 14 & 1.347 & 0.071 \\
Group 2 & 67 & 24 & 1.938 & 0.029 \\
Group 3 & 103 & 47 & 2.109 & 0.020 \\
Group 4 & 104 & 82 & 2.533 & 0.024 \\
\hline
\end{tabular}

with which it is associated, have a strong influence on the fauna of the Falkland shelf.

Among the species showing strong affinities to station group 2 stations are the euphausiid species Euphausia triacantha, E. similis and Stylocheiron maximum. The latter 2 species are not widely noted as being predominantly polar species, but are nevertheless considered to be widespread in the area (Dilwyn-John

ian shelf to the outer slope, group 3, the most oceanic stations along the $5000 \mathrm{~m}$ isobath and group 4 , the most northern stations. There is a particularly clear relationship between these faunal zones and the position of the water masses. Group 2 stations are found within the PFZ, group 3 stations dominate the eastern SAZ stations and group 4 stations exclusively occupy the STZ. It is important to note however that station group 2 is not limited to the PFZ but also occupies those stations immediately outside the bounds of the water mass. This distribution may be partly explained through examining the surface temperatures of the SAZ (Fig. 1) which are considerably lower in the region immediately adjacent to the PFZ than to the area further east. It is probable therefore that PFZ waters are a major influence on neighbouring SAZ stations through mixing across the SAF.

The dissimilarity matrix (Table 1 ) shows that station group 1, found on the Falkland shelf, is most closely associated to station group 2, the PFZ cluster. The species most strongly associated to station group 1 , although predominantly neritic, have widespread distributions throughout the survey area. Two of the species, the chaetognath Sagitta gazellae and the hyperiid Themisto gaudichaudii, are considered to be most strongly associated with colder, polar waters (David 1958, Bowman 1960, Hurley 1969, Mazzoni 1990). This would suggest that the PFZ and the Falkland Current.
1936, Mauchline 1980, Antezana \& Brinton 1981). E. triacantha and the other species found in this species cluster, Primno macropa, Salpa thompsoni and Protomyctophum bolini, are all characteristic of polar regions (Baker 1959, Barnard 1932, Foxton 1966, Smith \& Heemstra 1986) and are good indicator species of the PFZ. station group 3 . The first group contains 3 mesopelagic fish, Diaphus hudsoni, Argyropelecus hemigymnus and Lampanyctus pulsillus. The latter species are mainly sub-tropical species, whilst $D$. hudsoni is commonly found between the Sub-Tropical Convergence and $50^{\circ} \mathrm{S}$ (Smith \& Heemstra 1986). The second species cluster, containing Sagitta hexaptera, S. planctonis, Hippopodus hippopus and Chelophyes appendiculata, shows a joint affiliation to station group 4. As with the first species group, this group contains a mix of sub-tropical and sub-Antarctic species. Records of the chaetognath $S$. hexaptera are almost exclusively from the sub-tropical and tropical regions (Alvarino 1969, Boltovskoy 1981) whereas S. planctonis is relatively common in the Antarctic/sub-Antarctic zones (Boltovskoy 1975). H. hippopus and C. appendiculata are oceanic siphonophores and have been noted by Alvarino (1981) to have distributions between the equator and $46^{\circ} \mathrm{S}$, although there are records from as far south as $50^{\circ} \mathrm{S}$. Surface temperatures in this station
There are 2 species clusters showing association to

Table 4 . List of species occurring at more than $20 \%$ of stations grouped under the most strongly associated factors (parentheses indicate joint affiliation to 2 factors)

\begin{tabular}{|lcc|}
\hline Factor 1 & Factor 2 & Factor 3 \\
Hippopodus hippopus & Primno macropa & Euphausia longirostris \\
Chelophyes appendiculata & Euphausia triacantha & E. similis \\
Eukrohnia hamata & Sagitta gazellae & Rosacea plicata \\
Sagitta hexaptera & Protomyctophum bolini & (Stylocheiron maximum) \\
S. planctonis & (Stylocheiron maximum) & \\
Argyropelecus hemigymnus & (Themisto gaudichaudii) & Factor 6 \\
Factor 4 & Factor 5 & Gennadus valens \\
Euphausia vallentini & Salpa thompsoni (aggregate) & \\
E. lucens & S. thompsoni (solitary) & \\
(Themisto gaudichaudii) & Gymnoscopelus bolini & \\
\hline
\end{tabular}


group are notably high for sub-Antarctic water which may be caused by the extension of Brazil Current waters or the return of the Falkland Current warmed through contact with sub-tropical waters. This may enable these sub-tropical species to persist at latitudes that are further south than their normal range. It must
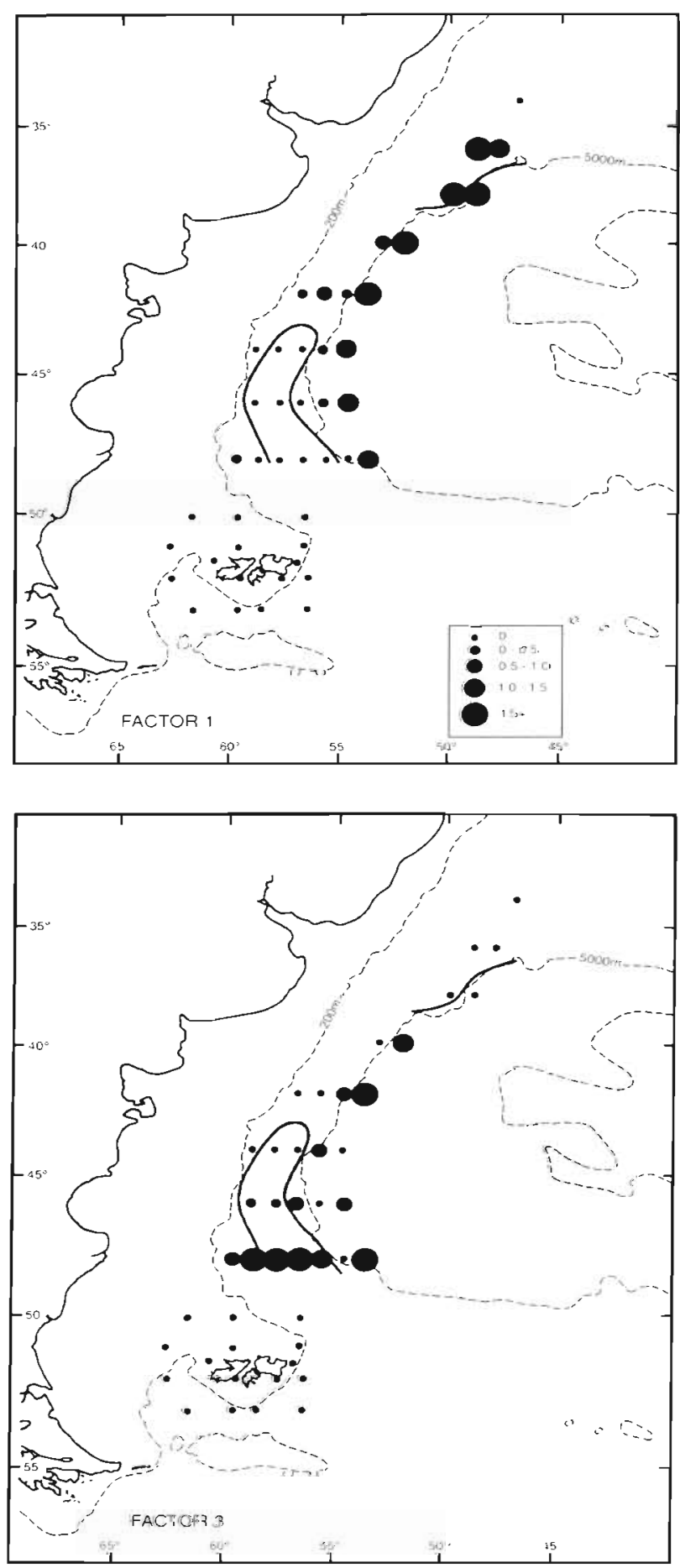

also be noted that many of the species associated to this station group are mesopelagic and may occupy different water masses below the sub-Antarctic surface water.

Station group 4 is the most distant group from each of the other 3 station groups in the dissimilarity matrix,
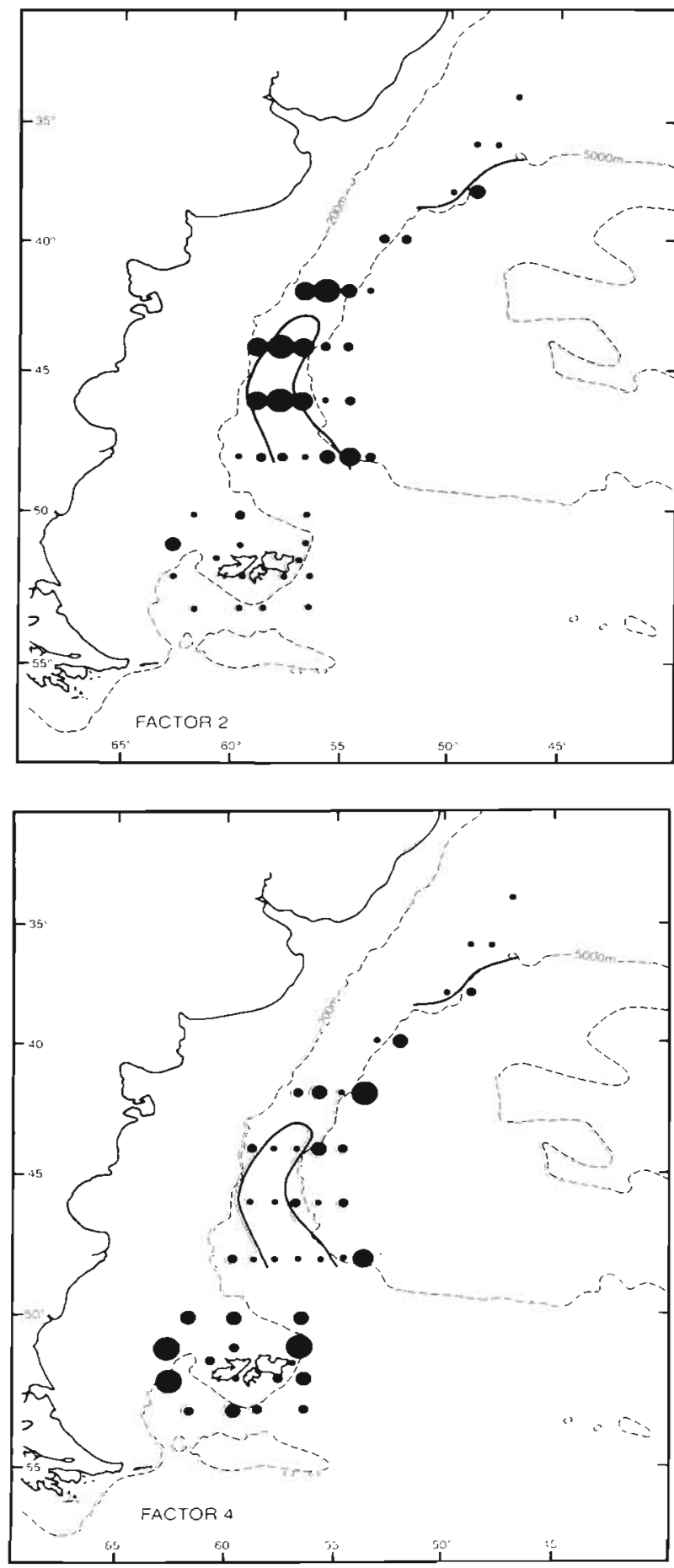

Fig. 7. The distribution of factor scores for the first 4 factors 
signifying that its fauna is distinctly different from that occupying the rest of the survey area. Table 2 shows that, although it has only 1 more species found within its zone compared to station group 3, it has almost double the number of species with strongest fidelity to the station group and by far the highest Shannon diversity index. Furthermore, 5 of the 8 species clusters show an association to this station group. The greatest contribution to the numbers of strongly associated species is made by hyperiid amphipod taxa, of which, from a total of 26 species found throughout the survey area, 22 are present and 9 are exclusively found at group 4 stations.

The high diversity and strong species fidelity of group 4 are characteristic features of central gyre communities (McGowan 1971, 1974). Nevertheless, a wider scoping study which included a more thorough consideration of the hydrography of the region would be necessary to verify that the gyre features of group 4 result from the influence of the South Atlantic Central Gyre. In station groups 2 and 3, although the actual numbers of species may be quite high, their fidelity to those regions is considerably lower than in station group 4 . These station groups are best considered as transition zones in which most of the species found together have their distribution centres elsewhere. Boltovskoy (1986) estimated that expatriate species make up 70 to $90 \%$ of the total inventory of the transition zone in the southwest Atlantic. Station group 1 , the Falkland shelf cluster, contains by far the least number of species, which is in keeping with most other studies comparing oceanic and neritic communities (e.g. Tremblay \& Roff 1983, Sabates et al. 1989, Atkinson \& Peck 1990). It is notable that most of the species associated with this station group were also relatively common at many off-shelf stations and it would therefore seem that the shelf community differs from the more oceanic groups only in the fact that many species have been excluded.

There is a considerable degree of overlap between the plots obtained from factor analysis and the results of the hierarchical classification analysis. Nevertheless, in being able to reveal the strength of a factor group's association to stations, factor analysis has given an extra degree of resolution and has revealed some interesting details. The species list and distribution of factor 1 strongly complies with that of station group 4. It is interesting to note however that the strongest associations are in the north and they weaken southwards. This would indeed fit with the hypothesis that this region is dominated by a subtropical fauna being carried beyond its normal range by the warm Falkland Current return. Factors 2 and 3 comply with station group 2 , but show a further separation between species found to be prominent in the northernmost projection of the PFZ and those predominantly limited to the $48^{\circ} \mathrm{S}$ transect. The faunal differences indicate that species with warmer affiliations are associated with factor 3 , along the $48^{\circ} \mathrm{S}$ transect. The surface temperatures of factor 3 stations are nevertheless colder than those of factor 2. The majority of factor 3 stations were sampled at night and despite controlling for day/night differences, it is possible that the separation of the 2 groups could have resulted from variance in patterns of vertical migration or avoidance.

Of particular interest is the distribution of factor 4 , which would otherwise comply with station group 1 but for a strong distribution in stations immediately north of the PFZ. Euphausia vallentini and E. lucens are neritic species common to the Falkland and Patagonian shelves and it is possible that their occurrence so far off-shelf is a result of being transported eastward by the Falkland Current as it encounters the Brazil Current. Curtolo et al. (1990) suggested that these species of euphausiids were transported along the shelf by the Falkland Current, although whether they make up the same population as those found north of the PFZ needs to be determined.

\section{Context of study}

Boltovskoy (1981) reviewed previous biogeographic charts of the southwest Atlantic Ocean. One of the first biogeographic charts that included the region was published by Mesenheimer (1905) and subsequent studies have been carried out by Steur (1933), Henschel (1938), Bogdanov (1961), McIntyre \& Be (1967), Nesis (1974). More recently Dadon (1989) and Mazzoni (1990) highlighted biogeographic zones along the Patagonian shelf. Though the biogeographic charts are similar in that they all distinguish warm-water and cold-water assemblages, there is little agreement over the number of distinct zones and the location of boundaries (Boltovskoy 1986). Many higher taxa respond differently to environmental variables and so the lack of agreement in such studies is somewhat inevitable considering that most concentrate on just 1 higher taxon.

Analysing patterns at the community level gives a more abjective approach to designating faunal zones, since the co-occurrence of a number of higher level taxa is being considered. It also brings the advantage of incorporating the biological as well as physical environment of a species into the factors affecting distribution. The community level study of Dadon \& Boltovskoy (1982) applied multivariate methods to literature-based records of euphausiid, pteropod and chaetognath distributions. The southwest Atlantic Ocean was divided into 75 sectors and literature records were used to determine the sectors in which a species was present or absent. An 
index of affinity for species pairs was used to generate groups of recurrent species and out of the 19 groups produced, 11 showed an affinity to designated hydrologic regions. The study resulted in the definition of $8 \mathrm{zoo-}$ geographic regions, the main ones being (I) Antarctic, (II) Sub-Antarctic, (III) Transitional, (IV) Sub-Tropical and (V) Tropical, with certain regions being further subdivided into neritic and oceanic sectors

Dadon \& Boltovskoy's study is subject to a number of limitations. The literature records consist of samples taken with a wide range of net designs with different selectivities and so there is a series of unaccountable biases within the data set. Furthermore, the nature of the study makes it impossible to account for seasonal biological variance and variation in the position of influential hydrographic features. Nevertheless the results are a useful classification of the zoogeographic zones averaged over the long term. with a resolution of approximately $3000 \mathrm{~km}$.

The above study has a much larger scale and coverage than this investigation, but there does appear to be a reasonable degree of agreement where the 2 study areas overlap. The species groupings are particularly consistent. For example, the recurrent group containing Euphausia lucens and E. vallentini in Dadon \& Boltovskoy (1982) complies with factor 4 and species cluster 2 of this investigation. Two further recurrent groups, Sagitta gazellae/Euphausia triacantha and E. longirostris/E. similis, are equivalent to factor group 2 and factor group 3 respectively. The distributions of these recurrent groups also match this study in 2 of the 3 cases. The E. lucens/E. vallentini recurrent group shows a mainly neritic distribution, similar to factor 4 , whilst the $E$. longirostris/E. similis recurrent group shows an association with a region between $50^{\circ}$ and $55^{\circ} \mathrm{S}$ corresponding to factor 3 . However, the S. gazellae/E. triacantha recurrent group is associated to a region much further south than the area covered by this survey and does not appear to comply with the distribution plot of factor group 2. The results of this survey show that $S$ gazellae/E. triacantha have a strong and definite relationship with the PFZ at lower latitudes. In the case of E. triacantha, these findings agree with those of Baker (1959), who recorded the strong occurrence of the species at these lower latitudes. The distribution of $S$ gazellae on the Patagonian shelf was studied by Mazzoni (1990) and it was found to be associated with a biogeographic area defined by the path of the Falkland Current, referred to as the 'Region Malvinense' This on-shelf area is almost directly adjacent to the off-shelf distribution of factor group 2.

The inadequacies of the data set limited Dadon \& Boltovskoy (1982) to defining megascale (Haury et al. 1978 ) zoogeographic zones. However, very few taxa occupy the full range of a zoogeographic zone whether it encompasses 1 or several water masses (Brinton 1962, E. Boltovskoy 1981). Investigating variations in abundance within these zones is an essential consideration at the community level since smaller scale patterns may highlight important influences on the larger scale distribution of a faunal group. The Falkland Current is a mesoscale feature that was shown by factor analysis to be a major influence on zooplankton distribution in this region. Factor 4, which contained neritic species, showed strongest associations to stations along the northward flow of the current including the occupation of off-shelf stations where, on encountering the Brazil Current, the Falkland Current moved in an eastward, oceanic direction. Factor 1, containing sub-tropical species, showed a pattern that decreased in strength as it moved southwards, suggesting that the warm Brazil Current extension/Falkland Current return caused the expatriation of species beyond their normal range.

The Falkland Current and other mesoscale structures such as eddies may have contributed to the further observation that the distributional ranges of faunal groups in the PFZ, SAZ and Falkland shelf were not always restricted by water mass boundaries, a feature previously observed by Bary (1963). Briggs (1974) and Fasham \& Angel (1975). Nevertheless, the distributions of station groups were firmly centred within the different water masses because, despite the fact that there were a number of common species, the abundances of these species varied considerably between water masses. The station group associated to the STZ, by contrast, was clustered according to the presence or absence of species since it contains a markedly different fauna and very few species found in the STZ were present beyond the southern limits of the water mass.

From data collected from this survey and a subsequent one in 1991, Rodhouse et al. (1992) investigated the relationship between water masses and cephalopod larvae. The STZ had the greatest number of species and individuals with 14 taxa and 42 specimens, the SAZ contained 9 taxa and 14 specimens and the PFZ, 3 taxa and 26 specimens. The species lists did overlap between water masses but there were some species found exclusively in either the SAZ or the STZ. It was concluded that there was a marked association between the distribution of cephalopod species and the water masses.

This study has shown that there is also a strong association between the water masses and the zooplankton communities in the study area, although the association is one based mostly on variations in abundance in the southern zones and on specific composition in the north. It is important to note that the results are only an integration of the top $300 \mathrm{~m}$ and that the selectivity of the net restricted the analysis to macrozooplankton. Furthermore, although an association with water 
masses is shown on a broad scale, it is also apparent that there are variations in abundance within faunal zones. In this region, it would appear that water mass boundaries are also faunal assemblage boundaries. Nevertheless, it is also evident that there are several community types restricted to certain regions within a single water mass.

Acknowledgements. We thank officers and crew of the MV 'Falkland Protector' for their assistance in the field and Dr P. Rodhouse (British Antarctic Survey) for the initial inception of this project and the granting of samples. Thanks are also owed to the following for their efforts in the on-shore logistics and for the deployment of gear and data collection at sea: Dr E. M. C. Hatfield, Douglas Bone, Elizabeth Marrow, Martin Collins, Conor Nolan and John Barton. G.T thanks Drs N. Merrett, P. Pugh, F. Pages, A. C. Pierrot-Bults, J.-P. Casanova and $P$. Hargreaves for confirmation on species identification, Dr D. Boltovskoy for advice on statistics, interpretation and reviewing manuscripts, J. Gibbs for construction of the Folsom splitter and J. Brooks for assistance with software. G.T was funded by a studentship from the Natural Environment Research Council (N.E.R.C.). The ship and field assistants were provisioned by the Falkland lsland government as part of their funding of research on commercially exploited cephalopods in the southwest Atlantic.

\section{LITERATURE CITED}

Alvarino, A. (1969). Los quetognatos del Atlantico distribucion y notas esenciales de sistematica. Trab. Inst. Esp. Oceanogr. 37: 1-290

Alvarino, A. (1981). Siphonophorae. In: Boltovskoy, D. (ed.) Atlas del zooplankton del Atlantico sudoccidental. Publ. esp. INIDEP, Mar del Plata, p. 383-390

Angel, M. V., Fasham, M. J. R. (1975). Analysis of the vertical and geographic distributions of the abundant species of planktonic ostracods in the north-east Atlantic. J. mar. biol. Ass. U.K. 55: 709-737

Angel, M. V. (1979). Zoogeography of the Atlantic. In: Van der Spoel, S., Pierrot-Bults, A. C. (eds.) Zoogeography and diversity of plankton. Edward Arnold, London, p. 160-190

Antezana, T., Brinton, E. (1981). Euphausiacea. In: Boltovskoy, D. (ed.) Atlas del zooplankton del Atlantico sudoccidental. Publ. esp. INIDEP, Mar del Plata, p. $681-694$

Atkinson, A., Peck, J. (1990). The distribution of zooplankton in relation to the South Georgia shelf. In: Kerry, K. R., Hempel, G. (eds.) Antarctic ecosystems, ecological change and conservation. Springer-Verlag, Berlin, p. 159-165

Baker, A. de C. (1959). Distribution and life history of Euphausia triacantha. 'Discovery' Rep. 19: 309-340

Barber, R. T., Chavez, F. P., Kogelschatz, J. E. (1985). Biological effects of 'El Niño'. ERFEN Boln 14: 3-29

Barnard, K. H. (1932). Amphipoda. 'Discovery' Rep. 5: 1-326

Bary, B. M. (1963). Temperature, salinity and plankton in the eastern north Atlantic and coastal waters of Britain, 1957 1l. The relationships between species and water bodies. J. Fish. Res. Bd Can. 20(4): 1031-1065

Bogdanov, D. V. (1961). Map of the natural zones of the ocean. Okeanologija 1: $941-943$

Boltovskoy, D. (1975). Some biometrical, ecological, morphological and distributional aspects of Chaetognatha. Hydrobiologia $46(4)$ : $515-534$
Boltovskoy, D. (1981). Chaetognatha. In: Boltovskoy, D. (ed.) Atlas del Zooplankton del Atlantico sudoccidental. Publ. esp. INIDEP, Mar del Plata, p. 759-774

Boltovskoy, D. (1986). Blogeography of the south-western Atlantic: current problems and prospects. In: Pierrot-Bults, A. C., Zahuranec, B. J., Johnson, A. C. (eds.) Proceedings of the International conference on pelagic biogeography. UNESCO, Paris, p. 14-24

Boltovskoy, E. (1981). Foramanifera. In: Boltovskoy, D. (ed.) Atlas del zooplankton del Atlantico Sudoccidental. Publ. esp. INIDEP, Mar del Plata, p. 317-352

Bowman, T E. (1960). The pelagic amphipod genus Parathemisto in the north Pacific and adjacent Arctic. Proc. U.S. nat. Mus. 112: 343-392

Briggs, J. C. (1974). Marine zoogeography. McGraw-Hill, New York

Brinton, E. (1962). The distribution of Pacific euphausiids. Bull. Scripps Inst. Oceanogr. 8(2): 51-270

Clarke, M. R. (1969). A new mid-water trawl for sampling discrete depth horizons. J. mar. biol. Ass. U.K. 49: 945-960

Curtolo, L. M., Dadon, J. R., Mazzoni, H. E. (1990). Distribution and abundance of euphausiids off Argentina in Spring 1978. Neritica 5(1): 1-14

Dadon, J. R. (1989). Pterapoda euthecosomata del mar epicontinental Argentino y adyencias. Universidad de Buenos Aires, Buenos Aires

Dadon, J. R., Boltovskoy, D. (1982). Zooplankton recurrent groups (Pteropoda, Euphausiacea, Chaetognatha) in the south-western Atlantic Ocean. Physis (Buenos Aires), Secc. A 41(100): 63-83

David, P. M. (1958). The distribution of the chaetognatha of the Southern Ocean. 'Discovery' Rep. 19: 199-228

Davies, W. K. D. (1982). Factorial ecology. Gower, Aldershot

Deacon, G. E. R. (1933). A general account of the hydrology of the South Atlantic Ocean. 'Discovery' Rep. 7. 171-238

Dilwyn-John, D. (1936). The southern species of the genus Euphausia. 'Discovery' Rep. 14: 193-324

Fasham, M. J. R., Angel, M. V. (1975). The relationship of the zoogeographic distributions of the planktonic ostracods in the north-east Atlantic to the water masses. J. mar biol. Ass. U.K. 55: 739-757

Fearon, J. (1986). The distribution and abundance of the dominant groups of epipelagic zooplankton off Namibia in Jan. 1985 in relation to surface temperature and chlorophyll. Collect. Sci. Paper ICSEAF 13(1): 215-227

Foxton, P. (1966). The distribution and life history of Salpa thompsoni with observation on a related species Salpa gerlachei. 'Discovery' Rep. 34: 1-116

Harman, H. H. (1967). Modern factor analysis. University of Chicago, Chicago

Hatfield, E. M. C. (1992). Recruitment, demography and growth of the Patagonian squid Lolngo gahi (d'Orbigny, 1835 in the Falkland Island waters. Ph.D. thesis, Council for National Academic awards (C.N.A.A.), London

Haury, L. R., McGowan, J A., Wiebe, P. H. (1978). Patterns and processes in the time-space scales of plankton distributions. In: Steele, J. H. (ed.) Spatial patterns in plankton communities. Springer-Verlag, Berlin, p. 277-327

Hentschel, E. (1938). Das Netzplankton des südatlantischen Ozeans, Eine Zusammenfassung. Wiss. Ergbn. dt. Atl. Exped. 'Meteor' 1925-1927 13: 245-308

Hurley, D. E. (1969). Amphipoda, Hyperiidea. In: Antarctic Map Folio Series (Folio 11). Distribution of selected groups of marine invertebrates in waters south of $35^{\circ} \mathrm{S}$ latitude. Amer. Geogr. Soc., Washington, DC, p. 32-34

Jespersen, P. (1923). On the quantity of macroplankton in the Mediterranean and the Atlantic. Rep. Danish Oceanogr. 
Expeditions 1908-1910.7:1-17

Jespersen, P. (1935). Quantitative investigations on the distribution of macroplankton in the different oceanic regions. Dana Rep. 2(7): 1-44

Kemp, S., Bennet, A. G. (1929). Discovery investigations: objects, equipment and methods. 'Discovery' Rep. 1. 1. -150

Lloyd, M., Zar, J. H., Karr, J. R. (1964). A table for calculating the 'equitability' component species diversity. J. Anim. Ecol. 33: 217-225

Mauchline, J. (1980). The biology of mysids and euphausiids. Adv. mar. Biol. 18: 1-681

Mazzoni, H. E. (1990). Chaetognatha del mar Argentino: cicIos estacionales de la distribucion espacial y otros aspectos ecologicas. Universidad de Buenos Aires, Buenos Aires

McGowan, J. A. (1971). Oceanic biogeography of the Pacific. In: Funnell, B. M., Riedel, W. R. (eds.) The micropaleontology of oceans. Cambridge Univ. Press, Cambridge, p. $1-74$

McGowan, J. A. (1974). The nature of oceanic ecosystems. In: Miller, C. B. (ed.) The biology of the oceanic Pacific. Oregon State University, Corvallis, p. 9-28

McIntyre, A., Be, A. W. H. (1967). Modern coccolithophoridae of the Atlantic Ocean. I. Placoliths and Cyrtoliths. Deep Sea Res. 14: $9-28$

Mesenheimer, J. (1905). Die tiergeographischen Regionen des Pelagias, auf Grund der Verbreitung der Pteropoden. Zool. Anz. 29: 153-163

Nesis, N. K. (1974). Okeanicheskie golovonogie mollyuski yugo-zapadnol Atlantiki. Trudy Inst. Okeanol. 98: 51-75

Peterson, R. G., Whitworth, I. T (1989). The sub-Antarctic and Polar fronts in relation to deep water masses through the south-western Atlantic. J. geophys. Res. 94(C4): $10817-10838$

Pillar, S. C., Stuart, V., Barange, M., Gibbons, M. J. (1992)

This article was submitted to the editor
Community structure and trophic ecology of euphausiids in the Benguela ecosystem. S. Afr. J. mar. Sci. 12: 393-409

Pommeranz, T., Herrmann, C., Kuhn, A. (1982). Mouth angles of the RMT1+8 during paying out and hauling. Ber. dt. wiss. Kommn Meeresforsch. 29: 267-274

Rodhouse, P. G., Hatfield, E. M. C. (1990). Dynamics of growth and maturation in the cephalopod Ilex argentinus (de Catellannos, 1960), (Teuthoided: Ommastrephidee). Phil. Trans. R. Soc. Lond. Ser. B 329: 229-241

Rodhouse, P. G., Symon, C., Hatfield, E. M. C. (1992). Early life cycle of cephalopods in relation to the major oceanographic features of the south-west Atlantic Ocean. Mar. Ecol. Prog. Ser. 89: 183-195

Sabates, A., Gili, J. M., Pages, F. (1989). Relationship between zooplankton distribution, geographic characteristics and hydrographic patterns off the Catalan coast. Mar. Biol. 103: $153-159$

Shannon, C. E., Weaver, W. (1963). The mathematical theory of communication. University Illinois Press, Urbana

Smith, M. M., Heemstra, P. C. (1986). Smith's sea fishes, 6th edn. Springer-Verlag, Berlin

Steedman, H. F. (1976). General and applied data on formaldehyde fixation and preservation of marine organ. isms. In: Steedman, H. F. (ed.) Zooplankton fixation and preservation. UNESCO, Paris, p. 103-154

Steur, A. (1933). Zur planmässigen Erforschung der geographischen Verbreitung des Haliplanktons, besonders der Copepoden. Zoogeographica 1. 269-302

Tremblay, M. J., Roff, J. C. (1983). Community gradients in the Scotian shelf zooplankton. Can. J. Fish. Aquat. Sci. 40: $598-611$

Van Guelpen, L., Markle, D. F., Duggan, D. J. (1982). An evaluation of accuracy, precision and speed of several zooplankton sub-sampling techniques. J. Cons. int. Explor. Mer 40: 226-236

Manuscript first received: July 1, 1994

Revised version accepted: December 28, 1994 